IRSH 46 (200I), pp. 393-42I DOI: I0.1017/S0020859001000256

(C) 200 I Internationaal Instituut voor Sociale Geschiedenis

\title{
Working Through Partition: Making a Living in the Bengal Borderlands*
}

\author{
WILLEM VAN SCHENDEL
}

Summary: Partition, the break-up of colonial India in 1947 , has been the subject of considerable serious historical research, but almost exclusively from two distinctive perspectives: as a macropolitical event; or as a cultural and personal disaster. Remarkably, very little is known about the socioeconomic impact of Partition on different localities and individuals. This exploratory essay considers how Partition affected working people's livelihood and labour relations. The essay focuses on the northeastern part of the subcontinent, where Partition created an international border separating East Bengal - which became East Pakistan, then Bangladesh from West Bengal, Bihar, Assam, and other regions which joined the new state of India. Based largely on evidence contained in "low-level" state records, the author explores how labour relations for several categories of workers in the new borderland changed during the period of the late i940s and I950s.

In the Indian subcontinent, the word "Partition" conjures up a particular landscape of knowledge and emotion. The break-up of colonial India has been presented from vantage points which privilege certain vistas of the postcolonial landscape. The high politics of the break-up itself, the violence and major population movements, and the long shadows which Partition cast over the relationship between India and Pakistan (and, from I97I, Bangladesh) have been topics of much myth-making, intense polemics, and considerable serious historical research. As three rival nationalisms were being built on conflicting interpretations of Partition, most analysts and historians have been drawn towards the study of Partition as a macropolitical event. Let us portray these scholars as the mountaineers of Partition studies.

A second trend in the literature has focused on Partition as a cultural and personal disaster, the fissure of two major regional cultures (Punjab and Bengal) which were divided between the successor states, and personal suffering and traumatic memories for millions of uprooted refugees. Those

* This article will also appear in Arvind N. Das and Marcel van der Linden (eds), Work and Social Change in Asia: Essays in Honour of Jan Breman (New Delhi, 2002). 
who study these themes are the fishermen of Partition, casting their nets in its deep waters. It is these two groups of scholars who have determined how we see the mental landscape of Partition - a landscape dominated by the jagged peaks of Mount Recrimination reflected in the dark surface of Lake Nostalgia.

Other parts of that landscape, however, are still in the shadows. We must explore them if we are to make sense of how Partition shaped social life in South Asia in the second half of the twentieth century. What lies between the mountains and the lake? What was happening in the foothills, on the plains, the rivers, and their banks? How did ordinary people experience the macropolitical event of state fragmentation? And how did their actions influence the shape of post-Partition societies?

We still know remarkably little about many aspects of Partition, particularly its socioeconomic impact on different localities and individuals. The nationalist historiographies of Pakistan, India, and Bangladesh have elevated the moment of Partition (I4/is August 1947) to the status of an absolute caesura in the history of the subcontinent. Till now, few have challenged the resulting state-centred periodization. But in many regions, and in the lives of numerous individuals, the realities of Partition were slow to make their mark. In their constructions of history, I 947 does not always appear as the sharp break of historiographical convention. Gyanendra Pandey's remarks for India are equally applicable to Pakistan and Bangladesh:

"The historians' " history of Partition has, in India, been a history of crisis for
the Indian nation and the nationalist leadership. It has been a history of the
machinations which lay behind this event, and the lessons to be drawn by
the nation for the future. This is not a history of the lives and experiences of the
people who lived through that time, of the way in which the events of the I 940 \%
were constructed in their minds, of the identities or uncertainties that Partition
created or reinforced. Even as a history of crisis for the Indian nation, therefore,
this history is inadequate. ${ }^{\text {I }}$

This inadequacy is even more glaring in the case of the historians' social and economic history of Partition. ${ }^{2}$ In order to construct adequate social

I. Gyanendra Pandey, "The Prose of Otherness", in David Arnold and David Hardiman (eds), Subaltern Studies VIII: Essays in Honour of Ranajit Guba (Delhi [etc.], I994), p. I94.

2. In the years following Partition, a few attempts were made to quantify the economic impact at aggregate levels (e.g. Vakil) and some studies have compared trends in East and West Bengal without focusing specifically on Partition (Boyce, Bose, Rogaly et al.). Studies such as Dasgupta's, comparing the long-term economic impact of Partition on a divided region, are very rare. C.N. Vakil, Economic Consequences of Divided India: A Study of the Economy of India and Pakistan (Bombay, 1950); James K. Boyce, Agrarian Impasse in Bengal: Institutional Constraints to Technological Change (Oxford [etc.], I987); Sugata Bose, Peasant Labour and Colonial Capital: Rural Bengal Since 1770, The New Cambridge History of India, vol. 3:2 (Delhi, 1993); Ben Rogaly, Barbara Harriss-White and Sugata Bose (eds), Sonar Bangla? 
and economic histories of Partition, we need to reconsider the historical sources which have informed Partition studies so far. Students of Partition have been returning time and again to a few particularly rich ores: highlevel state records (most famously the ones published in The Transfer of Power) ${ }^{3}$ as well as the private papers, correspondence, and memoirs of prominent politicians and bureaucrats. The possibilities offered by other source material have been much less diligently pursued. With few exceptions, the many voices speaking from low-level and local records, newspapers, diaries, letters, and oral and written testimony by ordinary people have been underused. 4

In this essay we consider how Partition affected working people's livelihood. India - much more than Bangladesh and Pakistan - has a lively tradition of labour history and labour studies.' Studies in this tradition often take 1947 as their cut-off point but otherwise they hardly intersect with studies on Partition. Many years ago, Jan Breman argued that "to understand the present situation of the rural labourers it is essential to know their position in the past", 6 and his impressive research output since then has done much to historicize the study of labour relations in South Asia. It is in this spirit that we explore the effects of Partition on labour, a topic which has received scant attention from students of labour as well as from students of Partition.

This is an exploratory essay, and its scope is restricted in several ways. First of all, it deals only with the northeastern part of the subcontinent, where Partition created an international border separating East Bengal which became East Pakistan, then Bangladesh - from West Bengal, Bihar, Assam, and other regions which joined the new state of India (see

Agricultural Growth and Agrarian Change in West Bengal and Bangladesh (Dhaka, 1999); Abhijit Dasgupta, Growth with Equity: The New Technology and Agrarian Change in Bengal (Delhi, I998).

3. Published in twelve volumes by Her Majesty's Stationery Office, London, between 1970 and I983, and edited by Nicholas Mansergh, E.W.R. Lumby and others.

4. Interesting recent examples of analyses on the basis of such material are Ritu Menon and Kamla Bhasin, Borders E Boundaries: Women in India's Partition (Delhi, I 998); Joya Chatterji, "The Fashioning of a Frontier: The Radcliffe Line and Bengal's Border Landscape, I947-52", Modern Asian Studies, 33 (1999), pp. I85-242; Dipesh Chakrabarty, "Remembered Villages: Representation of Hindu-Bengali Memories in the Aftermath of the Partition", Economic and Political Weekly (ro August 1996), pp. 2143-2I5I; Gautam Ghosh, "'God is a Refugee’: Nationalism, Morality and History in the 1947 Partition of India”, Social Analysis, 42 (1998), pp. 33-62; and Prafulla K. Chakrabarti, The Marginal Men: The Refugees and the Left Political Syndrome in West Bengal, 2nd edn (Calcutta, 1999).

5. For a recent overview, see Sabyasachi Bhattacharya, "South Asian Labour History: Historiography - And Where Do We Go From Here?", paper presented at the conference on Global Labour History in the Twenty-first Century, International Institute of Social History, Amsterdam, November 2000.

6. Jan Breman, Meester en Knecht: Een onderzoek naar de veranderingen in de betrekkingen tussen landheren en landarbeiders in Zuid-Gujarat, India (Amsterdam, 1970), p. 2. 


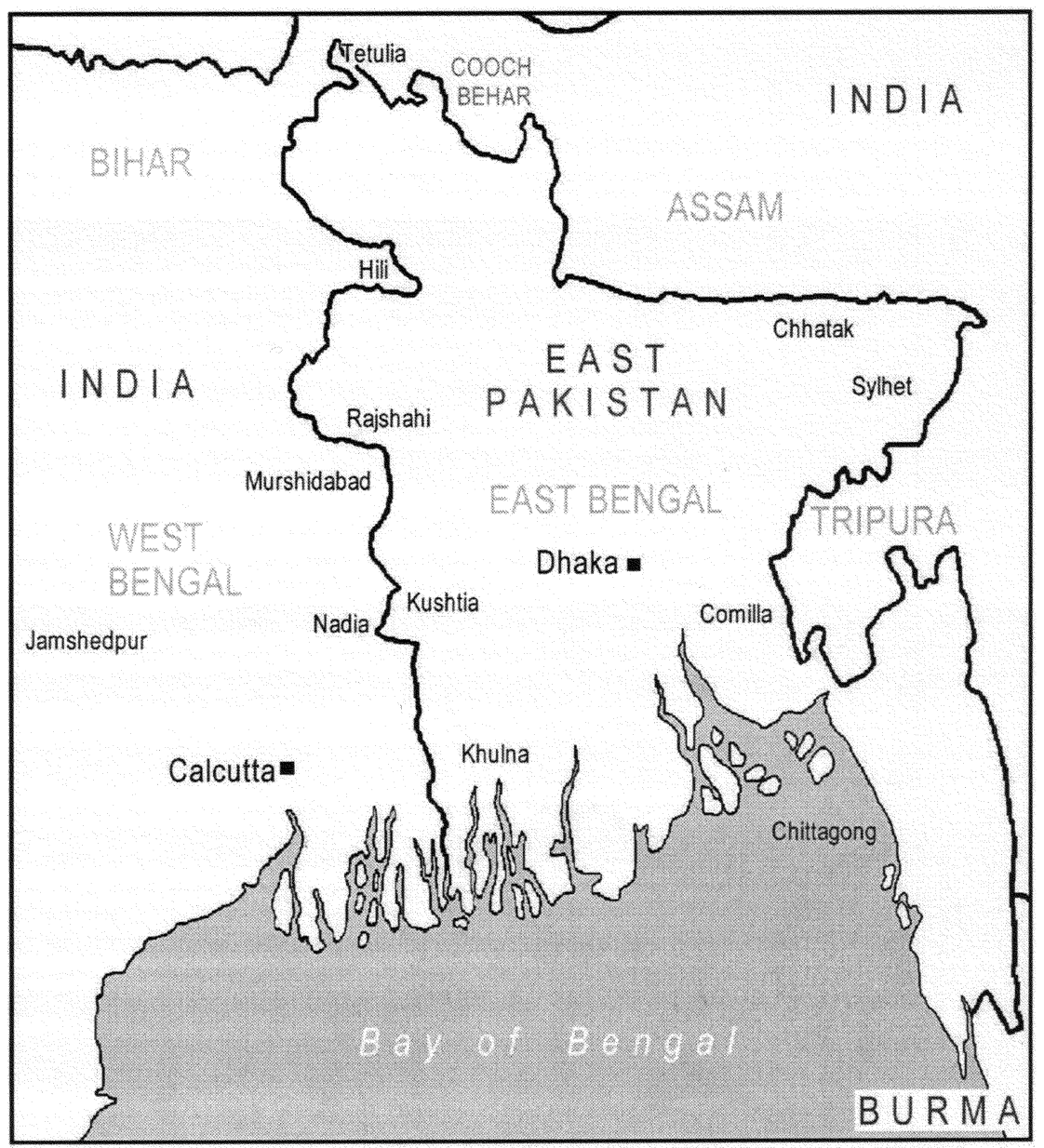

Figure I. The Partition border.

Figure I). Second, it concentrates on the new borderland and how labour relations changed there. Third, it is confined to the period of the late I940s and i950s. And finally, it is based largely on evidence contained in "lowlevel" state records. Because these records are more readily accessible in Bangladesh than in India, this essay contains more information on how people worked through Partition on the Pakistan side of the borderland than on the Indian side. ${ }^{7}$

7. In this paper, reference is made to three series of relatively "low-level" state records in the National Archives of Bangladesh in Dhaka. These are "B. Proceedings" of the Home Department of the Government of (East) Bengal, records which were supposed to be destroyed after a number of years. In the following, records of the Confidential Records Branch start with 
The aim of this essay is modest: to initiate the study of labour in the Partition borderland across the divide of i947. It does so by briefly introducing several categories of workers whose situation changed, often dramatically, as a result of Partition. The archival evidence on these changes is rather limited as state officials were interested only in certain aspects of labour, and their capacity for monitoring these was quite restricted. A more comprehensive understanding of how people "worked through Partition" requires the use of other sources, particularly oral ones.

Despite its limited scope, this essay underlines the need to rethink the categories of labour history in South Asia. In a recent publication, Jan Breman has analysed and criticized the narrowing of the focus of Indian labour studies to the study of urban industrial labour. ${ }^{8}$ This criticism is certainly relevant to the study of labour in the northeastern subcontinent. Here, students of labour have been concentrating most of their efforts on a minute section of workers in just one locality (Calcutta) and one industry (the jute industry). 9 As we shall see, industrial workers in Calcutta were among those directly affected by Partition, but the large majority of affected workers in the new borderland were rural and nonindustrial. The categories employed in this essay are broad, being based on "ways of earning a living", rather than on more restricted notions of labour as being waged, proletarianized, free, formal-sector, or organized. In the complex society of this region, much employment was nonwaged, or paid in services or kind, and wage employment often did not signify fully proletarianized labour. Most household incomes were made up of a number of sources: land, labour, and trade. ${ }^{10}$ The available evidence allows us to analyse sources of income but not how these were combined at the household level. Hence, the categories in this essay refer to individual ways of earning a living. I consider this a major weakness which can only be corrected, it seems, by oral histories of household living strategies.

\section{THE BORDER AS A BARRIER TO WORK}

Partition created an international border which stretched for over 4,000 kilometres, cutting through the provinces of Bengal and Assam. It ran

"CR", records of the Political Branch with "Plt.", and records of the Police Branch with "Police". I wish to thank the staff of the National Archives, in particular Dr Sharif Uddin Ahmed and Md Hashanuzzaman Hydary, for their help.

8. Jan Breman, A Study of Industrial Labour in Post-Colonial India, Working Papers on Asian Labour, No. 3 (Amsterdam, 1998). See also Jan Breman, Footloose Labour: Working in India's Informal Economy (Cambridge [etc.], I996).

9. See list of references in Bhattacharya, "South Asian Labour History".

I०. On the multiplicity of sources of income in rural Bengal, see Willem van Schendel, Peasant Mobility: The Odds of Life in Rural Bangladesh (Assen, 1981), pp. 302-303, 313-31 5, 320-322. 
along local administrative boundaries, through rivers, across fields, and along railway lines which had never before had much political or social significance. The border turned neighbours into citizens of different states, and often these neighbours entertained work relations with each other. They had to devise ways to continue these relations, or create new ones. Many found that the border did not change life overnight but only gradually came up as a barrier to crossborder work. Eventually, many were confronted with the stark choice between giving up their jobs or moving across the border to keep them.

\section{Wage labour}

The imposition of the border, and the population movements that took place as a result of it, had lasting effects on the labour market in the borderland. Both employers and labourers had gradually to adapt to new conditions which privileged labour ties on either side of the border and made crossborder labour ties less attractive. For example, a serious problem was how to take your wages home without being detected by the border police. The states of India and Pakistan, on bad terms with each other, prohibited the free flow of commodities across the border and returning wage labourers, whose wages were often largely in the form of food grains, were seen as smugglers. In I95 I,

Mangal Majhi [of Jakirpur village, West Dinajpur, India] worked as a day labourer in the house of Masoruddin Mondal of Bheram [the adjacent village in Dinajpur, Pakistan], who gave him one maund of paddy as his wages. He was arrested by a patrol constable of Rudrani Border Out Post within Pakistan territory while he was attempting to smuggle this paddy across the border. $\mathrm{He}$ was sent up in charge sheet and convicted. ${ }^{\mathrm{II}}$

The situation was even more complicated if wages were paid in cash. Pakistan and India imposed various restrictions on the import and export of currency, and border police could use this to harass crossborder labourers. ${ }^{12}$

But even day labourers who merely went to look for employment across the border could get into trouble. Jahura Bibi, a widow from Sylhet (Pakistan), sent her twenty-year-old son Taibullah across the border to find

I I. Government of East Bengal, Home (Political) Department, Confidential Records Branch, CR IB2-28/50 (B. Proceedings, November 1952); hereafter CR IB2-28/50 (I I-52).

I2. On I2 March 1952, Salam Mia, a day labourer of Hussanpur village (Tippera (Comilla) district, Pakistan), had the Pakistan Customs Liaison Officer enter into his Complaint Book: "I got Rs 5I/- at Agartala [in Tripura, India] as my wages for three month service. With the said amount I was coming to my home - Pakistan when I reached the India boarder, the Customs officer on duty seized the entire amount of Rs $5 \mathrm{I} /$ - and gave me a receipt for Rs 50/- only" (CR $3 \mathrm{I}-68 / 52(\mathrm{I}-54))$. 
her some employment. He did not return, so the next morning she went to the Indian side herself, only to find that he had been arrested. The police told her that her son "would be released if she could produce witnesses to prove that her son [was] not a spy". ${ }^{13}$ Two days later a similar case occurred, this time involving a labourer from a village in Tripura (India) who went over to Pakistan to find some work. Near the border, the labourer, Hiralal Das, was caught by a Pakistan border guard who suspected him of being a spy. Hiralal assured him that he was just looking for some work. The guard then proceeded to beat him up, after which he interrogated him about the strength of the military in Tripura, the location of the Tripura treasury, and where the Tripura royal family kept their valuables. As Hiralal could not give him any answers, the guard and a colleague beat him with their rifle butts, kicked him with their boots, and threatened to kill him. Eventually he was set free, returned to India, and filed a complaint with the local police. ${ }^{\mathrm{I}} 4$ It is clear that crossborder day labour held special risks but, nonetheless, it must have been very common. ${ }^{15}$

\section{Working for the other state}

A subset of border commuters, and one which is relatively well documented, were employees of the other state. During the colonial period many people had been employed by state institutions which were now in the other country. Their employment was not terminated because of that. For example, the district authorities of Rajshahi district (Pakistan) continued to employ boatmen from the adjacent district of Murshidabad (India). When these men got caught up in a border dispute between the two states in 1948, they "were severely beaten, arrested, remanded [in] custody [by the Indian authorities] and subsequently released on a bail of Rs 200/- each. Their relations are also being oppressed. Their fault is said to have $[\ldots]$ originated from the fact that they are serving under an enemy and hence are traitors." ${ }^{\prime 6}$

\footnotetext{
I3. $\mathrm{CR}$ I AI $-6 / 5$ I $(3-53)$.

I4. $\mathrm{CR}$ IA2-3/5 I $(3-53)$.

I 5. Another risk was being tricked into accepting a day-labour job across the border and then being arrested. This happened to Babar Ali, an Ansar (Pakistan volunteer) from Sylhet in 1952. Safu Mia from Tripura (India) asked him and two others to work in his field across the border in India. As they were working there, they were arrested by Indian police in connection with a recent theft. The plot had been hatched by Tamaruddin Addadar of Tripura who had asked Safu to engage Babar with whom he had "previous enmity [...] for some family affairs" (CR IA 7I/ $52(4-53))$.

I6. CR I I -I/49 (I-53). Another example from Murshidabad was Maulvi Zuadur Rahim of Kaitha village who worked as Head Assistant, Finance Department, Government of East Bengal (CR II-I 56/48 (I I-50)). Arabinda Gupta from Cachar (Assam, India) worked as Agricultural Demonstrator in Sylhet (Pakistan) (CR $3 \mathrm{I}-324 / 52$ (9-53)). Jatindra Nath Ganguly of Satkhira (Pakistan) was Khas Mahal Peon in 24-Parganas (India) (CR I A $3-8 / 49$ (I I-50)).
} 
Such state employees would commute daily across the border. But a much larger group of state employees, who worked for one state but lived in the other, served too far from their homes to commute daily. ${ }^{17}$ They remitted their earnings and visited their homes during holidays. Many of them worked as policemen, or in the armed forces. Their movements attracted little attention except when they got into trouble, usually because they were arrested while on home leave on suspicion of espionage. This happened to Santi Ranjan Chakraborty of Comilla district (Pakistan) who was arrested in $195 \mathrm{I}$. His father wrote to the East Pakistan authorities from his village home in Comilla:

I have the honour to state, that my eldest son Sreeman Santi Ranjan Chakraborty is an employee of Indian Navy, Bombay, before the partition of Bengal. He was coming on leave in his own house. After staying home some days he went to his father-in-laws house [...]. There he had been arrested [...]. He left his pay book, identity card, leave ticket, in Calcutta on the way of his coming from Bombay $[\ldots]$. He is the only person of earning in our family [...]. We live on his earnings only. ${ }^{18}$

Policemen regularly got into trouble when on home leave. Nurun Nabi, a constable at Tetulia (Pakistan), went home to Murshidabad (India) in I952 to give money to his mother. On his way back to Pakistan he was arrested near the border by a Bihar constable who robbed him and threatened to "shoot me dead in retaliation of the death of one Bharati havildar [Indian sergeant] who was reported to have been shot dead by the Pakistani police at Patagara (Bharat)". ${ }^{19}$

A complex case was presented by Haripada Biswas, from Khulna district, who worked for both governments at the same time. During the week, he was a permanent employee of the Office of the Accountant General, West Bengal, in Calcutta (India), and every weekend he was in

17. Just before Partition, some categories of state personnel were given the option to take employment in either Pakistan or India. For details on these Optee government servants, or Optees, see Md Mahbubar Rahman and Willem van Schendel, "I Am Not A Refugee': Rethinking Partition Migration"; paper presented at the Conference on Displaced People in South Asia, Chennai, 2-4 March 200I.

I 8. Letter from Nolini Mohan Chakraborty (Kashimpur village, PO Nashirkot, Dt. Tippera (Comilla)), I I/I2/5 I (CR IA 2-I/5 I (3-54)). For other cases of employees in the Indian Army and Air Force, see CR I A $3-8 / 49$ ( I I-50), CR I A6-I/52 (3-54); and CR I A2-I/5 I (3-54). The governments of Pakistan and India regularly exchanged armed forces personnel captured in the other country (CR IA6-I/52 (3-54)).

19. Nurun Nabi spent three months in an Indian jail and his case led to correspondence between the Ministry of External Affairs in Delhi and the High Commission for Pakistan in Delhi (CR IA6-I/52 (3-54)). For similar cases, see CR I A 3-8/49 (I I-50); CR I A6-I/52 (3-54); and $\mathrm{CR}$ IA2-I/5I $(3-54))$. 
Khulna (Pakistan) where he held the office of President of the Barrackpur Union Board No. IV. He was an Indian citizen. ${ }^{20}$

Unlike other crossborder commuters - whose employment never ended completely (although it was disrupted at times of border tension or war) and would expand considerably in the closing decades of the twentieth century - crossborder state employees found it increasingly difficult to continue after 1952, when India and Pakistan introduced passport and visa controls.

\section{Minding the shop}

The border also played havoc with the marketing system in the borderland which was based on rotating village markets. Village shops were relatively rare and goods reached customers through periodical markets which would assemble in substantial villages on two days each week. These days differed for individual villages in a region so there was always a market on in a nearby village. The border meant that, for borderlanders, marketing became a crossborder affair and exposed them to harassment by state personnel. ${ }^{2 I}$ The small town of Hili was cut in half by the border, and the market on the Indian side was deprived of "even fish and vegetables arriving by train to Hili Railway Station [which was in Pakistan]". ${ }^{22}$ Panchanan Poddar, who lived in the Indian half of the town, earned his living in the Pakistan part where he had a goldsmith's shop. In 1954, he was arrested in Pakistan on the grounds of not having the correct papers to work there. ${ }^{23}$

20. This double function seems to have created no problem, unlike his "actively agitating for the inclusion of the Khulna district in Bharat [India]". The District Magistrate of Khulna externed him from the district for "prejudicial activities" for six months in I950 (CR II-I2/50 (3-53), CR II-I6/53 (I-55)).

2I. E.g. on 30 March 1948 the Secretary to the Premier of West Bengal sent a long list of cases to his counterpart in East Bengal. One of these concerned eight merchants from Gangarampur (West Dinajpur, India) who had gone to collect "salt, mustard, dal, coconut oil, mustard oil, spices, soap, ground-nut, oranges etc from Dinajpur town [Pakistan] as usual. But the carts were detained near Pulhat and subsequently taken to Kotwali P.S. (Dinajpur). They were told that under no circumstances should anything go to the Indian Dominion from Pakistan. Eventually they returned all the articles [to those] from whom they had made the purchase but they did not get back the money." (CR IW-I/49 (I-53)).

22. Ibid.

23. The District Magistrate of Dinajpur [Pakistan] wrote to his colleague in West Dinajpur [India] in January 1955: "I am sure you would agree that persons like Panchanan Poddar should not receive your support or sympathy. Evidently, many people on either side of the border near Hili have been carrying on activities which offend against the Laws of both the countries besides harming their economic and financial interests" ( $\mathrm{CR} \mathrm{IB}_{2}-\mathrm{I}_{3} / 55$ ( $\left.\mathrm{I}_{2}-55\right)$; for a case of a shopkeeper who lived in Pakistan and owned a shop in India, see CR IA7-I/52 (4-53), 


\section{Crossborder landholding}

Perhaps the most extensive impact of Partition on work in the borderland had to do with agricultural work. In a strip more than $4,000 \mathrm{~km}$ in length, almost all of it rural, numerous cultivators found that they had become separated from their most valuable source of income, land. There were basically two ways in which this happened. First, landowners found that the border ran between their homes and (some of) their fields. In Bengal, land ownership tends to be fragmented, and it is quite common for even small peasants to own several small plots. Second, inhabitants of the borderland might decide to migrate across the border, thereby becoming separated from (some of) their fields. In either case, cultivators faced enormous organizational problems. Working the land on the other side of the border continued to be a common practice but there were several problems. How to protect the standing crop? How to take bullocks and ploughs safely back and forth across the border? How to make sure that you could take your harvest home without being accused of smuggling? And how to fight off claims by refugees on the other side of the border that your land there should be confiscated as enemy property and given to them?

It is clear that landowners followed various strategies to cope with this unprecedented situation. If fields were close to the borderline, they tended to do the cultivation work themselves, continuing much as in the past with family labour and occasional day labour. Where fields were too far away for daily inspection, or where militant new settlers would not allow the owners from across the border to cultivate their own fields, it was often best to give land in sharecropping, try to exchange it for land on the other side of the border, or sell it. In many cases these were not real options, as lands were simply occupied by newcomers who could not be made to leave. And where fields happened to be located in territory that was disputed between Pakistan and India (as was quite common along the undemarcated border), ${ }^{24}$ cultivation became impossible for years on end, and such fields would have to be left lying fallow.

It is impossible to quantify the agricultural disruption caused by the imposition of the border. A large number of state records dealing with crossborder landholding and conflict suggests, however, that it was massive. Often, local cultivators managed to involve border police in their conflict, creating a interstate incident. The following example is typical. In February I95 I the District Magistrate of Kushtia (Pakistan)

24. By I953, about 3,500 km (or 8 I per cent) of the border remained undemarcated, and by 1965 , about $\mathrm{I}, 500 \mathrm{~km}$ (or 34 per cent). India and Pakistan quarrelled over the exact location of many sectors of the border, and, even now, parts of the border remain unsurveyed and undemarcated. The same is true for the entire border between Bangladesh and Burma (Myanmar). 
wired his colleague in Nadia (India) that "Bharati [Indian] civilians backed by armed police have arrived at Bhatapara field to harvest paddy grown by Pakistani cultivators", and on the same day "one Reazuddin of village Shoulmari P.S. Meherpur was reaping paddy on his land with six labourers [when] thirty Indian nationals backed by armed police scared Reazuddin and his labourers away by your police firing six rounds and trespassed into Pakistan territory and removed the paddy cut by Reazuddin".25

Such crossborder landholding and cultivation was treated as an affair involving individual landholders' claims. But in one case it was treated as a collective affair. This was the case of the ziratia tenants. Certain parts of colonial Bengal and Assam had been ruled "indirectly" through local princes. These territories were not involved in the Partition of British India (i.e. the directly ruled parts) but were supposed to accede to either Pakistan or India. Two such princely states bordered East Pakistan, Tripura state in the east and Cooch Behar state in the north, and both acceded to India (see Figure I). A complication arose because both maharajas had not only been rulers over their own territories but had also been considerable landowners (zamindars) in "directly ruled" Bengal. ${ }^{26}$ After accession, they were rulers over Indian territory but at the same time landlords in Pakistan. This situation persisted till I952, when Pakistan abolished landlordism and the maharajas' holdings in Pakistan were taken over by the state.

In the case of the Maharaja of Cooch Behar this was a straightforward case of dispossession, but the Tripura case was much more complicated. The Maharaja of Tripura was the landlord of an enormous estate covering over 1,500 villages in the Pakistan borderland. ${ }^{27}$ Inhabitants of these villages also had land across the border in Tripura state and, in that capacity, were known as ziratia tenants. There also had been a customary right, from well before the colonial period, for them to gather wood and bamboo and graze their cattle in the hill forests of Tripura.

Partition caused this economy to unravel, and border people did not

25. CR IB2-II//I (3-53). The Kushtia-Nadia border was a hot spot for crossborder land conflicts at the time. For Pakistanis reaping crops on the Indian side, see e.g. CR $\mathrm{IB}_{2}-22 / 50$ $(5-52), \mathrm{CR}(2) \mathrm{IB}_{2}-22 / 50(5-52)$. Sometimes such conflicts were reported in newspapers. See Hindusthan Standard, i I January 1949 (cf. Government of East Bengal, Home Department, Police Branch, PioC-28/49 (B. Proceedings, June I949); hereafter: Police ProC-28/49 (6-49)). 26. The Maharaja of Cooch Behar was also zamindar of the Chaklajat Estates in the districts of Rangpur and Dinajpur. The Maharaja of Tripura was zamindar of the huge Chakla Roshnabad Estate in the districts of Tippera (Comilla) and Noakhali.

27. J.G. Cumming, Survey and Settlement of the Chakla Roshnabad Estate in the districts of Tippera and Noakhali, I892-99 (Calcutta, 1899), p. xvi. According to the Purbo Shimanto Pakistani Proja Union (Union of Tenants of the Eastern Pakistan Border), it yielded more than two million rupees annually; (Government of East Bengal, Home (Political) Department, Political Branch, CR IB-5 (B. Proceedings, December 1949); hereafter Plt. CR IB-5 (I 2-49)). 
take it lying down. Forming themselves into a number of organizations, ${ }^{28}$ they started petitioning the authorities in Tripura and Pakistan, explaining that both their agricultural work and the gathering of forest produce were being seriously jeopardized. ${ }^{29}$ They argued that "these Ziratia subjects can not enter their lands within the state. Tripura police militaries and Kirit Bikram Bahinies [a voluntary militia] are reaping the paddies of lands of Pakistanies in border at places". ${ }^{\circ}$ When the Tripura authorities continued to harass them whenever they crossed over to Tripura, they launched a norent movement on the Maharaja's estate in Pakistan. ${ }^{3 \mathrm{I}}$ In a leaflet entitled A Call for Preparation they stated: "we claim that the citizens of Pakistan bordering the Tripura State have full rights over the natural produce of Tripura State and no power on earth can deprive them of these rights", 32 and, in another leaflet, they made quite clear that "the incidents [...] constrain the Hindu and Muslim people of the Roshnabad [Estate] to adopt the following resolutions, and there is no communal motive behind them".33 The incidents did not stop, and ziratia tenants found it increasingly hazardous to work on the Indian side of the border.

In I95 I, the Tripura government initiated a policy of requisitioning land from Muslim landowners (including ziratias from Pakistan), in order to rehabilitate Hindu refugees from East Pakistan. ${ }^{34}$ Ziratia tenants found it increasingly dangerous to cross the border to work, either on their fields or in the forests collecting bamboo, timber and other forest products. The Pakistan authorities did not support them either. When Pakistan abolished landlord (zamindari) rights in the I950s, the Maharaja of Tripura lost his

28. Notably the Purba Simanta Pakistani Praja Union (Union of Tenants of the Eastern Borderland of Pakistan) and the Roshnabad Praja Samiti (Tenants Organization of the Roshnabad Estate) and its Committee of Action.

29. E.g. Roshnabad Zomidarir Shimantobashir O Tripura Rajyer Projagono Pokkhe Shrishrimoti Mohamanya Matamoharani Shomipe Binite O Shokorun Prarthona [A humble and woeful petition to Her Exalted Majesty the Queen Mother on behalf of the border people of the Roshnabad Estate and the subjects/tenants of Tripura State] 1949; Representation by Moulvi Sk. Wahidullah Chowdhary B.A., Secretary, Committee of Action, Roshnabad Proja Samiti, Feni (Plt. CRiB-s (I 2-49), Plt. II $-77 / 48(9-48))$.

30. $\mathrm{CR}$ IB $-3 / 48(9-49)$.

3. In a letter to the Secretary, Home (Inter-Dominion) Department (Tripura, India) of 30 November 1949, the District Magistrate at Comilla (Pakistan) wrote: "The Ziratia tenants are seeing me daily in large numbers, complaining of the troubles given to them by petty officials and other unfriendly elements. When they set foot in Tripura territory, they are chased out or threatened, intimidated and belaboured." In another letter to the Chief Commissioner, Tripura, the District Magistrate wrote that day: "The Ziratias are tenants of Tripura and their welfare and happiness is as much the concern of Tripura as ours, nay, even more"; (Plt. CRIB-5 (I 2-49)). 32. Ibid.

33. Ibid.

34. Published in the Tripura Gazette in the period March-June 195 I. See also "Tripura State", in Morning News (Dhaka), 23 April I95 I; letter to the editor, Pakistan Observer, I 2 June 195 I $\left(\mathrm{CR}_{3} \mathrm{~T}_{4}-\mathrm{I} / 5 \mathrm{I}(3-54)\right)$. 
huge income from the Chakla Roshnabad estate. By a stroke of the pen, his tenants in Pakistan were freed from their landlord, but they had to pay a high price; as landholders in Tripura they suffered a crushing defeat: they lost all their lands and income from the forests. Within a few years, they had changed from being regarded as the Maharaja's loyal subjects to being seen as Pakistani foreigners without any rights. The state of Pakistan diverted the income from the Chakla Roshnabad estate to its own coffers. It compensated the Maharaja lavishly but the ziratias were not compensated in any way. By the late I950s, crossborder landholding in this part of the borderland, whether by superior tenure holders such as the Maharaja or by lowly ziratias, had come to an end. ${ }^{35}$

In all these cases - wage labour, marketing, and crossborder landholding and forest rights - the new international border acted as a barrier. It cut off individuals and households from sources of income on which they had depended and forced them to replace these with new ones. The border forced labour, produce and land markets into a new territorial straitjacket, and borderlanders had to adapt their living strategies accordingly. Crossborder relations never disappeared completely but they were subject to new uncertainties and risks. For some borderlanders, however, the new barrier itself was a workplace.

\section{THE BORDER AS A WORKPLACE}

Many people had been working on what was now the new Partition border. Some continued to do so and others found employment because of the border. The various ways in which these border workers negotiated the new dangers and opportunities was crucial in giving different sections of the borderland their particularly local characters. ${ }^{36}$

About $\mathrm{I}, 000 \mathrm{~km}$ of the border actually ran through water, and those who worked on the border rivers and marshes faced a dangerous but potentially lucrative situation. Local ferries suddenly became illegal or

35. In 1957, ziratia rights were linked to railway transit facilities for Indian grain through East Pakistan to Tripura. In exchange for these facilities, ziratias were allowed to take up to 40 maunds ( $\mathrm{I}, 440 \mathrm{~kg}$ ) of paddy per family from Tripura to East Pakistan. When this transit trade was blocked, however, these last remaining ziratia rights lapsed. See Shreedhar and John Kaniyalil, Indo-Pak Relations: A Documentary Study (New Delhi, I993), pp. I37-I 40 . See also "Kumillay Purbo Pakistan o Tripura Rajjo shommelon: Shimanter golojog o bibhinno shomosshar mimangsha prochesta", Azad, i3 October 1949.

36. See Andrew Walker, "Borders, Frontier Communities and the State: Cross-River Boat Operators in Chiang Khong, Northern Thailand”, Canberra Anthropology, I9:2 (1996), pp. I-28. 
(rarely) blossomed into officially designated border crossings. ${ }^{37}$ They turned into crucial nodes in new networks of crossborder commuting, migration, trade and smuggling. Rivers had always been important avenues of traffic and trade, linking coastal Bengal with inland towns and villages. Regular steamer services had provided public transport, often over hundreds of kilometres, and goods had moved primarily over water. As a result of Partition, however, some of the most important river routes simply died, together with the river ports that had depended on them and the employment they had generated. Large border rivers became too dangerous for steamers (e.g. the Ganges (Padma)), and officials would reject local demands for re-establishing steamer stations out of fear of facilitating smuggling. ${ }^{38}$ Trade in small boats on the smaller border rivers and fishing in border marshes, lakes, and rivers became risky because of disagreements over where the actual borderline was located. Not surprisingly, those who operated nondesignated ferries and country boats on border rivers (often wage labourers employed by the boat owners) frequently found themselves the target of crossborder shootings. Their work was suspect because of its location: here the line between legal trade and smuggling, exploitation of domestic and foreign resources, and being a citizen or an alien was wafer thin. Nobody has ever bothered to record how many boatmen and fishermen lost their lives on the border rivers over the years, but the records are full of border incidents in which they were involved. 39

The land borders were usually easier to locate. Over a period of years, considerable stretches were demarcated and marked by boundary pillars but some areas remained undemarcated, and even border guards were not exactly sure where the border was. Indian, Pakistani and Burmese villagers who worked near the border had to be careful: straying cows often crossed the line and the responsible cowherd could get harassed, arrested, or killed by border guards. Woodcutters in deep forest might cross the border

37. If border ferries were allowed to continue, they were also taxed, sometimes by both states. It took until 1952 before such double taxation was removed in the case of the ferry between Balla (Sylhet) and Khowai (Tripura). This agreement was extended to all sixteen "inter-dominion ferries" in 1955 (CR $3 \mathrm{I}-104 / 52$ (7-54); $\mathrm{CR}_{3} \mathrm{C}_{\mathrm{I}-2 / 55}$ ( I I-55)).

38. On the death of the steamer service on the Ganges, see Willem van Schendel, "Easy Come, Easy Go: Smugglers on the Ganges”, Journal of Contemporary Asia, 23 (1993), pp. I 89-2 I 3 . On the refusal to allow a steamer station at the border town of Zakiganj in Sylhet in I95 I, see Plt. $32 \mathrm{C}-\mathrm{I} / 5 \mathrm{I}(3-53)$.

39. On boatmen being arrested, shot at, or killed by border guards, see e.g. Police EBProC-23 (9-48); CR IB2-I I/50 (3-5I); Police PIoC-I $2 / 49$ (I0-49); CR IB2-I/5I (2-54); CR IBI-

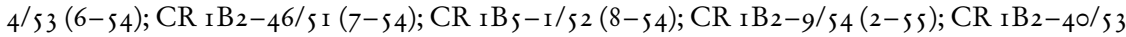
(I 2-55); on fishermen: $\mathrm{CR}_{\mathrm{IB}} 2-6 / 49$ (7-52), and CR $3 \mathrm{I}-20 / 53$ (I I-54); on char inhabitants: CR I W I I I/5 I (5-53), CR IB I-4/53 (6-54). Others whose work took them to the border rivers were also at risk, e.g. collectors of stones in the Pyain river on the Assam/Sylhet border (see CR IAI-6/5 I (3-53)). 
unawares and get attacked or, in more recent times, blown to pieces by an antipersonnel mine..$^{\circ}$ Cultivators with land in areas which both Pakistan and India claimed could work their fields only at great risk or under the protection of border guards. ${ }^{4 \mathrm{I}}$ And finally, the work of border guards itself was fraught with danger: shoot-outs between border guards were an important tool for India and Pakistan to give expression to their territorial disagreements.

\section{Manning the border}

One of the first consequences of Partition was a sudden need to police the new border. To this end, the states created new sets of border personnel. Immediately after Partition, the situation was chaotic. First, voluntary militias were formed, often with state support, in which refugees were usually prominent. ${ }^{42}$ There were many different outfits, some of them short-lived, and it was a major task for the state to impose some semblance of a monopoly of policing the borderland. Spontaneous vigilante parties and party-based groups (like the Indian Congress Volunteers and the Muslim League National Guards) had to be streamlined into state-based militias. On the Indian side of the border, the paramilitary volunteers were usually known as Home Guards, although there were several other names. ${ }^{43}$ On the East Pakistan side, volunteers were assembled in the new Ansar organization. ${ }^{44}$ Discussions about this force were initiated in October 1947. "At first the names 'Home Guard' and 'National Guard' were tentatively used, but the name 'Ansar' was adopted as expressing within itself, with historical and religious significance, the whole ideal of voluntary service to the community and to the nation." 45 Although "membership of the organisation would be entirely honorary and voluntary, and open to all Pakistanis between 18 and 48 years of age", many Ansars in the border areas were soon absorbed into the police force, in

40. CR II-I6/48 (Part) (II-50), CR II-I20/48 (I-5I). "Mine explosions along Myanmar border: 57 Bangladeshi woodcutters killed in 18 months", The Daily Star, 4 June 1998.

4I. E.g. $\mathrm{CR}+\mathrm{B}_{2}-33 / 52(3-54)$.

42. CR II-I $20 / 48$ (I-5I); cf. CR IB $3-\mathrm{I} / 49$ (3-5I).

43. E.g. the Assam Home Guards, the Bihar Home Guards, Tripura Rakshmi Bahini (Tripura Protection Corps), Jatiya Rakshmi Bahini (National Protection Corps), Banga Rakshmi Bahini (Bengal Protection Corps), West Bengal National Volunteer Force. The last three may be alternate names for the Bangiya Jatiya Rakshi Dal (Bengal National Protection Brigade), formed in March 1948; Chatterji, "The Fashioning of a Frontier", pp. 237-239.

44. Police $\mathrm{I}_{3} \mathrm{C}-\mathrm{I}$ ( $\left.10-48\right)$.

45. James Buchanan, "First Annual Report on the Ansars" (1948); in Police ProA-76/49 (I I-49). 
order to man border outposts and prevent the smuggling of jute to India. ${ }^{6}$ In this way, they became waged servants of the state. ${ }^{47}$ On the Indian side, volunteers were similarly used by the state in guarding the border..$^{8}$

The state offered other important employment opportunities on the border, especially in the Customs and Excise Departments which grew rapidly. Customs officials were active at a number of designated border crossings and at railway stations in the borderland. ${ }^{49}$ They soon acquired a reputation for bullying, harassment, extortion, and theft; $5^{\circ}$ in order to control them, Pakistan and India decided to employ "customs liaison officers" who were stationed on each other's territory, and who could be a approached by people with a complaint against customs officials. ${ }^{5 \mathrm{I}}$

All this employment was new, and it was much sought after by members of hitherto independent militias in the borderland, as well by immigrants. These jobs were popular because they provided an entry into the state bureaucracy, and therefore promised a steady income, career prospects, and prestige: public recruiting drives attracted many more hopeful young men than could possibly be given jobs.

46. The number of border outposts grew rapidly. For example, in 1949, Pakistan increased the number of border outposts on the North Bengal border from 85 to 162 . The outpost had been manned by a border militia which was then withdrawn as it was deemed unreliable (i.e. involved in smuggling). In their place came Ansars who had been absorbed into the Border Police (CR IC-2/50 (I I-50)). See Chatterji, “The Fashioning of a Frontier”, pp. 236-237.

47. Police ProA-76/9 (i I-49), Appendix C.

48. Although it is not clear from the evidence at hand whether this included paying a wage. In the early 1950s, according to the Provincial Commandant of the West Bengal National Volunteer Force (WBNVF), "a good number of volunteers" joined the Indian border outposts. On 19 December 1953, five of them were arrested by Pakistani border police in Khulna district for crossing the border without any papers. During their "usual night patrol" in the Basirhat area (in India) the unarmed volunteers had encountered smugglers who had put up a fight and forced them to flee to the Pakistan side (CR I A2-2/53 (10-54)).

49. There was continual pressure from local authorities to increase the number of "land customs stations" in order to legalize crossborder trade, which was going on anyway, and to allow the state to tax it. But since the establishment of such official customs stations required that both India and Pakistan agree, the opening up of a local customs station could easily become a pawn in complex diplomatic games between the two governments. (Plt. $32 \mathrm{C}-\mathrm{I} / 5 \mathrm{I}(3-53)$ ); $\mathrm{CR}_{3} \mathrm{C}_{2}-5 / 50$ (3-53); CR I ICI-9/52 (I-54); and CR 3I-239/5I (8-54)). At times, positions in the customs department were created in an attempt to block crossborder trade, as when East Bengal tried to stop jute smuggling to West Bengal in 1949 (CR IC-2/50 ( I I-50). By I954, there were less than three dozen check posts on "a border of I 700 miles" (CR 8M-I/54 (I-55)).

50. See letters of victims of highhandedness: e.g. $\mathrm{CR}_{2} \mathrm{R}_{3}-9 / 5 \circ(3-53)$; CR $10 \mathrm{C}-9 / 50$ (5-53);

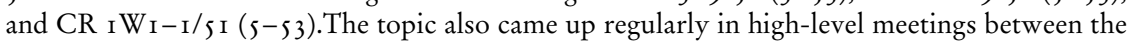
governments of East Bengal and West Bengal (e.g. CR ${ }_{3} \mathrm{C}_{2}-5 / 50(3-53)$ ).

5I. The Delhi Pact of 1950 stated: "There shall be no harassment by the Customs authorities. At each Customs post agreed upon by the Governments concerned, liaison officers shall be posted to ensure this in practice." ( $\mathrm{CR} \mathrm{IC}-\mathrm{I} / 50(\mathrm{II}-50))$. For examples of complaints against harassment, see $\mathrm{CR}{ }_{1} B_{3}-2 / 50$ (7-52); CR 26A-I/50 (I 2-52); $\mathrm{CR} 3 \mathrm{I}-68 / 52$ (I-54); and $\mathrm{CR}$ I ICI-4/53 (2-54). On liaisons officers, see also CR I $\mathrm{A}_{7-1 / 52}(4-53)$. 


\section{Borderland industries}

Little is known about the effects of the border on industries which were located in the new borderland. Some industries found themselves actually straddling the new border. For example, from precolonial days, lime burning had been an important cottage industry on the border of two administrative units in Assam, Sylhet, and the Khasi and Jaintia Hills. In I943, a cement factory had been started here. When Assam was partitioned, Sylhet fell to Pakistan and the Khasi and Jaintia Hills became part of India. The factory was in Chhatak in Sylhet, some ten kilometres from the new border, but its raw material was in India. Even though there was no official border crossing along this entire stretch of border, this sole cement factory in East Pakistan survived. In I 953 an official reported: "the transport of lime stone from the Kasi and Jiantia Hills [sic] in Assam takes place by the rope-way of the Assam Bengal Cement Factory and coal from the Boshera colliery in India is transported by river route to the factory".52 But supplies were insufficient, and the factory could produce only half its capacity until limestone quarries in Pakistan came into production and the kilns and boilers were converted from coal to gas firing in 1960. Employment at the factory, in the quarries, and in the colliery was adversely affected, but not eliminated, by the imposition of the border.

As a workplace, the border was a mixed blessing. We have seen that its creation forced many workers to look for alternative ways of earning a living whereas it provided new jobs to others. Those who worked on or near the border were exposed to unprecedented danger because violence could easily erupt in the tense atmosphere between two nation-building projects at loggerheads.

\section{THE BORDER AS A RESOURCE}

Before Partition, there had been considerable trade flows crisscrossing what would become the borderland. After August 1947, the new states had to devise policies to cope with the fact that such trade had suddenly turned into international flows. However, neither India nor Pakistan could develop a straightforward trade policy; they were pulled in different directions. 53 On the one hand, the two states sought to disentangle the

52. CR IrCi-9/52 (I-54). See also East Pakistan District Gazetteers: Sylhet (Dacca, 1970), pp. I $5-17,190,193-194,370$.

53. Little is known about Burma's trade policy vis-à-vis East Bengal. In the early years after independence, the government in Rangoon had little say over the regions bordering on East Bengal and only gradually established control. Initially, there were problems as the currencies of Burma and Pakistan were not convertible (see "Rangoon o Pak-Borma shimante mudrar jor chorakarbar ...”, Azad, 29 May 1949). Trade relations were much less restricted by political considerations in this section of the borderland. 
economy of partitioned regions in order to integrate their portions of the regions into their own national economies. But, at the same time, they were keen to profit from any crossborder trade which they saw as supporting their own national cause because it provided strategic or scarce goods, or because it could be taxed.

As a result, a high level of uncertainty surrounded border trade, and borderlanders were continually picking up clues as to the newest obstructions and opportunities. Trade which was encouraged yesterday might be criminalized today, only to be tolerated unofficially tomorrow. 54 In other words, the creation of the border set up a new, haphazard dynamic that nobody in the borderland could control. Right after the establishment of the border, the flow of certain goods was interrupted or hampered, other goods continued to flow freely, and yet others began to flow in response to new opportunities opening up. Borderlanders soon learned that this pattern of flow and blockage would be subject to sudden and unpredictable change.

The best documented case of disruption is the movement of jute fibre from the fields of East Bengal to the jute mills around Calcutta. The case of jute shows the coercion and resistance which was involved in such disruption, particularly in the borderland. The new border separated the jute industry from its raw material, and it made perfect economic sense to continue the trade which had existed for about a century. But it did not make political sense. The Pakistan government was keen to develop a jute industry of its own and forbade the export of jute. Since it could not offer the prices that jute fetched across the border, the jute trade was driven underground. Selling jute to Calcutta suddenly became an antinational act.

For this reason, the Pakistan state had to give special attention to the borderland. New border outposts were established on the West Bengal/ East Bengal border to curb the smuggling of jute to India. In 1949, the Pakistan Jute Board concluded that earlier measures to curb smuggling to India had not had the desired effect, that "smuggling is still going on on a fairly large scale", and that "the smugglers were being actively helped by certain elements in the Police, Ansars and Customs Staff".s5 For this reason the government organized a Jute Purchase Drive in the borderland. Thirty purchase teams were formed whose task it was to "comb through each section [of the borderland] and buy as much jute as possible". It was clear that they expected resistance. The mood among jute growers in the borderland was described as one of growing discontent because they were

54. For example, in December 1950, the export of vegetables and fish through a ferry crossing on the Sylhet-Tripura border was suddenly disrupted, apparently merely as a result of a new contingent of Pakistan armed forces being posted there (CR 5 T-I/50 (2-53), also for similar cases).

55. CR IC-2/50 (I I-50); $\mathrm{CR}_{\mathrm{IB}} \mathrm{B}_{2}-35 / 5$ I (I-55). 
forced to hold on to large stocks of jute "strangulated in villages" and therefore faced financial crisis. ${ }^{6}$ For this reason, the purchase teams were accompanied by armed Ansars.

In many other cases, crossborder traders also defied the state. Many parts of East Bengal produced paddy which was sold to deficit areas that were now across the border in India. The East Bengal authorities were keen to stop this, and special police officers were given the task of preventing paddy leaving the country. This was not an easy task, as events after the first major post-Partition harvest in December 1947 showed. One officer wrote to his superior for support. Describing himself as a "helpless but undaunted servant of Islam and Pakistan", he explained that, after he had been stationed on the border at Rajshahi, "I became aware of a large area in Murshidabad district opposite my camp faced with an acute crisis and the smugglers on our side disastrously active. I set to work at once and was successful in stopping this huge drainage of food grains from Eastern Pakistan." He was then threatened by smugglers, armed Indian border guards, and a landlord, but persisted "as a selfless Guard of my National Home". 57 Some of his colleagues, however, failed to stop a breakthrough:

On I I January I948, no less than 500 boats laden with paddy were taken through Chanchkoir, on the river Atrai in Rajshahi, on their way to India. Police ordered them to stop but as there were only a few policemen, they proved no match for the many armed men accompanying the boats. The next day the police learned that paddy boats were assembling up-river again. This time the Cordoning Officer detailed his men for duty. That afternoon, a fleet of boats accompanied by at least sixty armed men on the river banks came rushing towards Chanchkoir. The boatmen and their protectors shouted "Allabu Akbar!" (God is Great!) and refused to listen to the officer telling them to stop and show their permits. On the contrary, they attacked and wounded him with a pointed bamboo. He fled to a police boat. The crowd pursued him by jumping into the water and caught up with him in mid-river. Then the officer ordered his men to open fire, jumped into the river himself, and swam across with the crowd in hot pursuit. The police party fired in all directions for twenty minutes, using I०2 rounds of ammunition, while the men surrounded them and pelted them with bricks. Then the paddy boats squeezed past the police party, collected about twenty injured men and four dead bodies, and disappeared towards the border. ${ }^{8}$

56. $\mathrm{CR}$ IC $-2 / 50$ (I I-50).

57. Letter from Syed Ghulam Nabi Ahmadi, Patrol Officer, Ghughumari Ghat and Panka Ghat, to the Regional Controller of Procurement, through the Regional Cordoning Officer, Region I, Rajshahi, 25 February 1948 (CR IW-I/49 (I-53)).

58. "Report of the Executive Enquiry on the Firing Resorted to by the Armed Police Party Posted at Chanchkoir on I2.I.48”; (Police P5R-10/48 (10-48)). 
Similarly, in April I950, two border guards in the northern district of Rangpur were on patrol when they came across "a large number of Hindu migrants with about a thousand heads of cattle and other restricted articles proceeding towards Cooch Behar [India] by a village path”. When told by the senior guard to proceed to India through the prescribed customs route, they did not pay heed to his instruction but "adopted a defiant attitude and tried to assault him".59

It is likely that such confrontations occurred often. And it was not only thwarted pre-Partition trade which was at issue. Soon new commodities also found their way across the border, and a lively two-way network of unauthorized trade, or smuggling, developed. It provided many borderlanders with an income as traders, coolies, ferrymen, and day labourers of various descriptions. ${ }^{60}$ In this way, the border developed into an important resource for workers in the borderland.

\section{THE BORDER AS A REFUGE}

Partition resulted in the movement of large numbers of people, some of them labour migrants but others refugees. The border acted as a refuge for those who were driven from their place of work by discrimination, or fear of violence. Among the many groups affected were "minority" workers, i.e. Hindus in industries in East Bengal (Pakistan) and Muslims in industries in West Bengal (India). Our information is largely restricted to Muslims working in factories in West Bengal. The late I940s and early I950s were a period in which categories of citizenship and religious affiliation were seen as closely intertwined. Till I952, when citizenship became more formalized, with the introduction of passports and visas between India and East Pakistan, it was not always clear who was a citizen of which country. Did one's place of domicile make one a citizen of the state that controlled that territory? Was one's religion a sign of citizenship - being Muslim signifying Pakistani citizenship and being non-Muslim (especially Hindu) signifying Indian citizenship?

In both countries, communal intimidation was used to promote citizenship-by-religious-community, and communal violence, or the threat of such violence, became an important instrument for driving out Muslims from India and Hindus from Pakistan. When communal violence occurred in industrial settings in West Bengal, local Muslim workers might

59. The confrontation ended in arrest, and confiscation (and subsequent auctioning) of cows. A petition, accusing the police of demanding a huge bribe, was later filed by Rupkanta Barman and five others from a village in PS Dimla (Pakistan), suggesting that these were local Rajbongshi cattle traders rather than emigrants $\left(\mathrm{CR} \mathrm{IA}_{3}-5 / 50(3-54)\right.$.

60. See van Schendel, "Easy Come, Easy Go". 
feel forced to leave for East Bengal and so become Pakistanis. ${ }^{6 \mathrm{I}}$ This happened to Mehbub, now a citizen of Bangladesh, who remembered his family's flight from Calcutta during riots in 1950:

My name is Mehbub. I am from Kankinara, Calcutta, 24-Parganas. I was born there. My father had migrated to Kankinara from Bihar, from Arrah district. $\mathrm{He}$ was a foreman (shordar) in a jute mill - a very important man. His name was Haji Abdur Razzak. He was a Line Shordar at the Bhatpara Jute Mill, and later at the Gouripur Jute Mill and then the Haora Jute Mill [...]. We had a lot of property there - we still do but it is all illegally occupied now: our house, a cinema hall and land [...]. We left all that because of a huge riot that broke out in I950. We had to leave our neighbourhood and gathered in one place. There we were besieged from all sides. The government took a decision and Sarojini Naidu told us: "You go to Pakistan". Then they loaded us onto trains like pilgrims. There were separate carriages for us in the trains at Sealdah Station. We could not take any possessions with us. Only the clothes we were wearing. From there we went to Ishurdi [in East Pakistan] and then to Rajshahi. [Over here,] Father began a copper and brass business [...]. He returned to India in 1958 but he did not get back our old house. Instead he rented a house in Noyabazar (Kankinara) and took a job in a jute mill again. He is dead now but my nephews still live there, in India. They are doing well. ${ }^{62}$

This case reveals Mehbub's family's multiple identities in terms of both class and citizenship: Mehbub's father, a foreman in a factory, was also the owner of an enterprise. After 1947, he became an Indian citizen but changed his citizenship to Pakistani after fleeing there in 1950, only to return to India eight years later where he died as an Indian citizen.

But some Muslims working in Indian industries were officially considered as Pakistani citizens on the basis of their religion as well as their place of origin. This was the case with several thousands of Muslims from East Bengal who were working as permanent labourers in the industrial belt of Jamshedpur (India). ${ }^{63}$ Before I947, many of them had been active members of the Muslim League and had supported the campaign for Pakistan. According to the High Commissioner for Pakistan in India, who took up

6r. For example, in March 1949, an anti-Muslim riot occurred in Kankinara, a mill town near Calcutta where, according to Dr B.C. Roy, the Premier of West Bengal, in his statement in the West Bengal Assembly, "the majority of the residents are Muslims and up-country Hindus working in the mills. Periodically they fall out and disturbances ensue". During the Holi festival, a Hindu sprinkled coloured water "on a Muslim belonging to the Kankinara Jute Mills and residing in the coolie lines of those mills". This set off a riot resulting in several casualties and the temporary closure of the mills (CR $5 \mathrm{R}-2 / 49(3-50)$ ).

62. Mehbub, interviewed by Md Mahbubar Rahman, Rajshahi (Bangladesh), February I 999. For more on migrants and refugees in the borderland in the I940s and I950s, see Rahman and Van Schendel, “'I Am Not A Refugee”".

63. Almost 3,300 East Bengali Muslims were reported to work in io large steel and other factories in Jamshedpur and Asansol (Bihar, India) in March 1949, remitting more than Rs 400,000 to their families back home each month (CR I "O"-3/49 (3-54)). 
their case in 1949 because he considered them Pakistan nationals, they had "declared their allegiance to the Dominion of India" after the division of the two countries, but were being "victimised by the local authorities for their past activities". The Indian authorities replied that only a small number of "Pakistani Muslims" had been detained or deported for "indulging in subversive activities which could not be ignored". ${ }^{64}$

In early 1950, widespread rioting in both India and Pakistan, in which Mehbub's family got caught up, forced large numbers of Muslims to flee to East Bengal and large numbers of Hindus to flee to India, especially to West Bengal, Assam, and Tripura. Among the Muslim refugees were some 30,000 industrial labourers from West Bengal. It is not clear how many of these refugees were "Pakistani" in the sense of being labour migrants from East Bengal, and how many were "Indians", being Muslims from West Bengal, Bihar, or other parts of India. ${ }^{65}$ According to an agreement reached between Pakistan and India, the governments of West Bengal, Assam, and East Bengal would persuade employers of industrial labour to reinstate returning refugees to their old jobs. ${ }^{66}$ The government of West Bengal was unwilling to implement this agreement, and the result was that hardly any Muslim refugees could return to their old jobs. The industrial labour force in West Bengal was renewed with locally recruited, largely Hindu, labourers. ${ }^{67}$ This lack of reinstatement remained a bone of contention between East and West Bengal for years. ${ }^{68}$

\footnotetext{
64. Ibid.

65. Although the vast majority of Muslim labourers in West Bengal industries felt that their lives were in danger if they stayed in their jobs, a select group of Muslims working in strategic industries (electricity works, arms factories) were given state protection in special Muslim protected quarters; Abdus Satter, “An Eye-Witness' Report on Greater Calcutta Mill Areas; Latest Situation As On I 5-7-50”, (CR 3I-I $54 / 52$ (3-53)).

66. This agreement, known as the Delhi Pact or the Nehru-Liaquat Pact in India (LiaquatNehru Pact in Pakistan), was signed on 8 April I950; the statement about industrial labourers was included in the annexe of I5 August I950 (CR IC-I/50 (I I-50)).

67. The government of West Bengal pleaded inability to persuade employers to take back the refugee Muslim labourers despite "doing their best and using whatever influence they had with the mill authorities". They pointed to the fact that "under standing orders in force in Jute Mills, a workman was liable to be dismissed for absence without leave for more than Io days", and that the employers, faced with a serious labour shortage after the riots, had had to employ new hands. Also, "the sudden defection of these workers seriously hampered national production. The vacancies caused by their continued absence had to be filled in by new recruits to prevent further loss to production." If refugee labourers would now approach their former employers for reinstatement, this was "likely to disturb the peace in the mill area as the Sirdars who are now in control of the mill area (and are said to be overwhelmingly Hindus), might create trouble". "Proceedings of the Meeting Held at Calcutta on I4th October I950 in Connection with Reinstatement of Industrial Labour" and other documents in CR II-I8/53 (I I-55).

68. The West Bengal government could trace only 192 reinstated labourers, out of over 8,000 names provided by the East Bengal government (CR II-I8/53 (II-55)). The issue of reinstatement was on the agenda at the periodic conferences of the Chief Secretaries of the two governments, starting with the eighteenth conference in November I950 (CR II-3/5 I ( I I-
} 
Whenever political tensions between India and Pakistan intensified, as happened frequently, workers in the Calcutta region who had links with Pakistan immediately felt the repercussions. ${ }^{69}$ A good example is the fate of forty Muslim porters and gatekeepers (darwans) who had been employed by the Titagarh Jute Mills since i937. While most labourers left quietly, they decided to go out with a bang.

A few days before the Indo-Pak relation became strained over the Kashmir issue [in I95 I], the mill-owners appointed a number of Hindu darwans. Very subtly estrangement was created between the old darwans and the newly recruited ones. As a result the Muslim darwans started to feel that it was no more possible to work with self-respect. They thought that the circumstances were against them. In order to escape retrenchment, they resigned in a body. They got 3 months pay and of these 40, I4 decided to return to their native place in Pakistan and they engaged a few drummers. In the evening of Ioth August, they were arrested on their way. It was learnt that police permission was necessary to take out a procession in Titagarh and this they did not obtain..$^{\circ}$

Industrial workers, like others, fell victim to the painful process of minority expulsion that followed Partition. Both religious community and place of origin were crucial markers in the early years. Gradually, the two coalesced as formal citizenship criteria became more important..$^{71}$ Little is known about the employment strategies of displaced industrial workers from Calcutta. In East Bengal, many tried to join the new Pakistan armed

53); see $\mathrm{CR}{ }_{3} \mathrm{CI}_{\mathrm{I}-2 / 55}$ ( I I-55). At that time, it was clearly risky for industrial labourers from East Bengal to return to West Bengal to demand reinstatement on their own. Returning refugees were often jailed on suspicion of being spies. Even claiming arrears of pay could end in disaster, as in the case of two labourers from Jessore who were arrested in Calcutta in $195 \mathrm{I}$ on "the pretext that they were Ansars"; (CR IA I-3/5 I (2-54)).

69. Developments in industrial employment in East Bengal mirrored those in West Bengal. In June 1953, the East Pakistan Labour Journal published a speech by the Labour Minister in which he stated that, in industrial concerns, only Pakistan nationals should be employed and that the tea industry (where non-Muslim labourers from India had long been employed) must appoint a certain percentage of Pakistani Muslims (CR $\left.{ }_{3} \mathrm{C}_{\mathrm{I}}-3 / 54(9-54)\right)$.

70. Shadhinota (Bengali daily, Calcutta), I2 August I95 I (cf. CR IAI-8/52 (7-54)). These labourers, who were not from East Bengal but from Punjab and the North-West Frontier Province, apparently had had their arrival accompanied by music as well. See Arjan de Haan, Unsettled Settlers: Migrant Workers and Industrial Capitalism in Calcutta (Hilversum, 1994), p. 174, n. 23.

7I. Although Pakistani/Bangladeshi labourers disappeared from the payrolls of the Calcutta jute industry, Muslims did not. In 1950, the number of Muslims in Victoria Mill decreased from over I,700 to less than 800 , and "for years after that, no Muslims lived in the lines owned by the mill”; De Haan, Unsettled Settlers, p. 174, n. 23. In one jute mill studied by Fernandes in the early I990s, 20 per cent of the labourers were Muslims. The labour force was overwhelmingly nonBengali: 66 per cent from Bihar, Is per cent from Uttar Pradesh and only 7 per cent from West Bengal; Leela Fernandes, Producing Workers: The Politics of Gender, Class, and Culture in the Calcutta Jute Mills (Philadelphia, PA, I997), p. 64. 
forces and paramilitary outfits..$^{72}$ Others attempted to find jobs in the budding jute industries of the Narayanganj region. Very few appear to have followed the example of Mehbub's father who returned to an industrial job in Calcutta some years later.

If little is known about the employment effects of Partition on workers in urban industries, much less is known about the effects on industries in the borderland itself. That these could be devastating is attested to by a report on the handloom industry in the East Bengal/Burma borderland. Weaving had long been the mainstay of the Rakhain (Arakanese Buddhist) population of the southern Chittagong district. Partition cut them off both from their source of raw material and their market. They produced various silk textiles for the Burmese market which, because of new import and export restrictions, now became so difficult to reach that most producers had to abandon their trade. Many switched over to the production of cigars and cheroots, for which local tobacco could be used. This seemed to offer a solution until the Pakistan government decided to slap a double duty:

[...] once on raw tobacco and then on cigars and cheroots [...]. Due to this latter tax, the manufacture of cigars and cheroots by these people ha[s] stopped as they cannot find a market. The market is flooded with foreign cigars and cheroots which are sold at cheaper rates than the local products. ${ }^{73}$

As a result, "being unable to cope with the changed conditions [the Rakhain] have already begun in hundreds to migrate to Burma against their will just in an attempt to save their lives"..$^{74}$

It is often difficult to say whether crossborder migration was primarily due to political or economic causes. The industrial labourers from Calcutta fled targeted violence and ended up in reduced economic circumstances in East Pakistan. For them the border was a political refuge. The Rakhain weavers migrating from East Pakistan to Burma took refuge behind the border for economic reasons, fleeing state policies which made it impossible for them to earn their living.

\section{REGULATING CROSSBORDER WORK}

The many forms of earning a crossborder living described above were predicated upon a curious time-lag in the imposition of effective

\footnotetext{
72. Captain A. Ghani of the East Pakistan Recruiting Office reported that a crowd of more than 5,000 gathered in front of the Noakhali Circuit House on I 4 March I950 in the hope of getting a job in the armed forces. "The majority of the crowd comprised of the dislodged workers of Dunlop and Batta Companies due to communal riot" (Plt. $3 \mathrm{R}-64 / 5$ I (3-52)).

73. U Chin, "Report on the Migration of Arakanese Buddhists to Arakan" (1953), in CR $9 \mathrm{M}-\mathrm{I}_{4} / 53(6-54)$.

74. Ibid.
} 
restrictions on crossborder travel in the Bengal borderland. In this respect there was, for five years after Partition, a sharp difference between the two wings of Pakistan: "Entry into Pakistan by permit is binding on those persons who wish to come to Western Pakistan. So far no permit is required for entry into East Pakistan."75 This meant that crossborder travel between India and East Pakistan and vice versa was almost completely uncontrolled. Citizenship in India and East Pakistan became more strictly regulated only in 1952, with the introduction of passports and visas. Monitoring crossborder population movement was a principal aim, and visas for citizens of the neighbouring country were different from those for other nationals. It was clear, however, that neither state was quite up to scrutinizing all movement across a $4,000 \mathrm{~km}$ borderline. In fact, India and Pakistan actually institutionalized the practice of crossborder commuting at this time: commuters were allowed special visas with which they could cross the border without being checked. ${ }^{76}$ In order to get a visa, one would, of course, need a passport, but most people in the borderlands continued to cross without any official papers.

This arrangement did not take into consideration older systems of seasonal labour migration which after 1947 had become crossborder movements. For example, it had been common for labourers in Sylhet to harvest paddy locally and then move on to tea gardens elsewhere in Assam or Tripura. In 1947, Sylhet was detached from the rest of Assam and incorporated into Pakistan. The labour shortages in the Assam tea industry

75. Police Pi4M-i67/49 (10-49).

76. From 1952, Pakistan issued category 'A' visas for "the following Indian nationals who live in Indian territory within ten miles of the East Bengal border and who normally earn their livelihood by working in Pakistan territory within ten miles of the East Bengal border: (a) cultivators who have to make frequent journeys in order to cultivate or supervise the cultivation of their own lands and their labourers and hired servants; (b) small artisans, such as blacksmiths, wood-cutters, carpenters, petty shopkeepers and petty traders; and (c) persons the only market for whose agricultural produce lie in Pakistan territory within ten miles of the East Bengal border." These visas were "valid only for the village in East Bengal, including villages lying en route". Holders could cross the border at any place within the villages specified (and not through an official check post) and as often as they wished. They were exempt from registration. The visas were valid for a period of up to five years. There were also category ' $E$ ' visas for Indian transport workers and businessmen. Passport System to Regulate the Entry of Indian Nationals into Pakistan (Karachi, 1952), in Plt. 2B-I7/52 (3-53); cf. CR 8M-I/54 (I-55). See CR IB I-4/ 53 (6-54); CR 3A-10/53 (8-54); $\mathrm{CR}_{3} \mathrm{I}-436 / 53$ (8-54); and $\mathrm{CR}{ }_{1} \mathrm{~B}_{3}-\mathrm{I} 6 / 53$ (I I-54) for implementation of these rules at the border district level. In 1954 Pakistani officials estimated that the number of East Pakistanis holding visas of category ' $A$ ' was four or five times the number of Indians holding visas of that category; CR 8M-I/54 (I-55). In addition, special arrangements were made for those who repaired telephone and telegraph lines on the border, members of survey parties engaged in demarcating the border, and contractors, workers, and masons charged with constructing boundary pillars; $\mathrm{CR} \mathrm{IB}_{2}-\mathrm{I} 9 / 54(7-54)$. 
could not be met locally, however, and seasonal migration from Sylhet continued, although now the migrants, as Muslims and Pakistani citizens, were more vulnerable and faced the risk of being robbed on their way home. ${ }^{77}$ In Tripura, labour contractors also continued to resort to recruitment from Sylhet. Suggestions were made to regulate this labour migration by means of permits, a recruiting centre, or a labour exchange..$^{8}$ The strained relationship between India and Pakistan prevented the regulation of seasonal labour migration, and this may have contributed greatly to the permanent migration of settlers from East Pakistan to Northeast India in the following period. 79

Crossborder population movements between East Pakistan and its other neighbour, Burma, were even less formalized. In the colonial period, there had been an important stream of internal labour migration from Orissa and Madras through Bengal to Arakan. ${ }^{80}$ After 1947, however, following this trajectory meant crossing two international borders (from India to Pakistan and from Pakistan to Burma). Still, migration persisted, organized by commissions agents in Akyab (Burma) and Chittagong (Pakistan). This gave rise, as far away as Karachi and

77. In March 1948, “Asmatullah and others of Sylhet district were returning from Digari Tea Estate in Sib Sagar where they went to earn as day labourers, when the train reached between Lalting and Hatikuli, the checker checked their tickets and gave an indication to some Hindus, who attacked them, beat them, and took their belongings including their cash money amounting to Rs ir 28/10. The police and the public did not come to their rescue. They saw Muslims of Tippera, Noakhali and Sylhet, their co-passengers in other compartments being beaten and robbed of their money by the Hindus.” Matters for Consideration of the Conference of the Chief Secretaries at Calcutta on the roth May, 1948 (CR II-I6/48 (Part) (I I-50)).

78. In 1952, the East Pakistan Federation of Labour reported that 10,000 Pakistani labourers were working, under very bad conditions, on a new road that would link Agartala (the capital of Tripura) with the rest of India. "The contractors have failed to proceed with outside labours recruited from Bharat, the Pakistani Labours have proved best worker with less payment. [...] it is high time to consider, if Pakistani Labours should be allowed to complete [the] work of the Road in the enemy country. [...] If the Govt of Bharat [India] wants the services of these Pakistany Labours, it might be done in a regulated way with the knowledge $\&$ concent of the both the Dominions"; CR $3 \mathrm{I}-274 / 52$ (3-53). In I950, the Federation had appeared to be in favour of continuing the system, but in a regulated way; $\mathrm{CR}_{3} \mathrm{~T}_{\mathrm{I}-\mathrm{I} / 5 \mathrm{I}}$ (553).

79. The issue of providing migrants with work permits resurfaced in the late I990s in the context of debates in India regarding "infiltration" from Bangladesh. See e.g. Partha S. Ghosh, "Illegal Immigration from Bangladesh - II", The Hindu, I2 August I998; Anindita Ramaswamy, "Govt Sees Work Permits as Solution to Influx Problem”, Financial Express, I 8 September I 998; Sanjoy Hazarika, "Managing the Migrants in the Northeast", Indian Express, 29 January 1999; Sanjoy Hazarika, "Turn Migration to India's Benefit", Times of India, 27 April 1999; Anindita Dasgupta, "Thinking With the Head: Foreign Nationals in Assam”, The Daily Star, 6 May 1999. 80. Until 1937, this entire area was part of the colony of British India. After 1937, Burma (including Arakan) became a separate British colony. 
Rangoon, to bureaucratic anxiety about "surreptitious" and "unauthorised emigration of Indian Nationals through East Bengal to Burma". ${ }^{8}$ In addition, harvesting Arakan's rich paddy lands had long been entrusted to migrant labour from the southern Chittagong district. This too now became a crossborder movement and as entry of foreign labour into Burma became more difficult, "the landholders of Akyab [...] encourage permanent settlement of those labouring classes who go there with their family. They are supplying food, shelter and land to these emigrants". The Pakistan authorities estimated that about I 0,000 people had migrated from Pakistan to Burma between March and June 1948. ${ }^{82}$ That the flow of labour across the Burma-Pakistan border was not completely unregulated, however, is clear from the case of up to 50,000 Muslims from Arakan who fled to the Pakistan side in 1948. Three years later, the All-Burma Rwangya Refugee Organisation (East Pakistan) at the border settlement of Nhila used a visit by the Burmese consul to ask him to move the Pakistan government to introduce a "permit system to facilitate their going to Burma for earning their bread". ${ }^{8}$

In short, state regulation of crossborder work affected on a small proportion of those who earned a living on or near the border. In effect, except for the categories mentioned in the visa rules, the states of Pakistan and India did not attempt to regulate crossborder work at all but neither were they capable of stopping it. Since few crossborder workers cared to get the official papers which allowed them to work across the border either because they did not know about the rules, had no money for passports and visas, made local arrangements with border guards, or simply took a chance - state regulation was even more marginal than the limited attempts indicate. After 1952, all kinds of crossborder work continued, now with the added, but in most cases remote, risk of getting arrested for trespassing.

8I. See correspondence between the Pakistan Ministry of Foreign Affairs and Commonwealth Relations (Karachi) and the Deputy High Commissioner for India in Pakistan (Karachi) in 1949 (Plt.7F-I/49 (I0-50)). According to the Pakistan Embassy in Rangoon, the Burmese ViceConsul in Chittagong had been issuing temporary seasonal permits; there were no formal restrictions on seasonal labourers to the labour-deficient region of Arakan.

82. Answers by the Home Minister, Government of East Bengal, to questions in the East Bengal Legislative Assembly, io September 1948; Plt. I2C-37/48 (I 2-50).

83. These Chittagonian-speaking Muslims from northern Arakan (later known as "Rohingyas") were compelled to leave their ancestral homes as a result of a deliberate Burmese policy to remove them in an attempt to root out "Muslim insurgents". Massacres by armed forces occurred on Io and I I November I948, and the military told surviving "Rwangyas that unless they vacated Maungdaw and Buthidaung they would be tortured and butchered like animals and that they were appointed to wipe out the Rwangyas from Maungdaw and Buthidaung"; CR $\mathrm{IV}-\mathrm{IO} / 5 \mathrm{I}(5-53)$. 


\section{CONCLUSION: WORKING THROUGH PARTITION}

The sudden creation of two new states, Pakistan and India, in 1947 is usually studied from the perspective of the resultant centres of state power and the symbolic creation of two nations. This essay has focused on another arena: the borderland, where nations demarcate their imagined homelands and states and define the margins of their territories and jurisdictions. This is where nations and states meet in geographical terms, and it is this physical confrontation which makes borderlands such essential sites for the study of nations and states, and, indeed, partitions.

The inhabitants of borderlands develop relationships with state organizations and national identities which are, of necessity, more ambiguous than in the territorial heartland: borderlanders are daily reminded of the reality, and the inherent opportunities and risks, of two competing political projects. In their social and economic behaviour, borderlanders have to find pragmatic solutions which frequently flout state rules. Hence, they are often depicted as subversive, not only because they expose the weaknesses of state control but also because many illegal crossborder activities are only possible with the complicity of state agents. ${ }^{84}$

The inability of even the most powerful states to bring "subversive" border economies under control is well documented, not least in the case of unauthorized workers. ${ }^{85}$ For this reason, the study of labour in borderlands can be illuminating; it provides insights into the relationship between labour and the state which differ from those obtained from the more conventional sites of labour studies. And because bureaucrats and politicians worry about what goes on in borderlands, they tend to collect and preserve relatively much information on labour relations there.

In this essay, we have seen how the struggle between states and borderlanders in search of a living unfolded in a new borderland, and how that struggle worked out for different groups of borderlanders. In the wake of state fragmentation, many found earning a living hard whereas for others new opportunities opened up. The vignettes presented in the foregoing pages point to a host of questions about the relationship between Partition and borderland labour. To what extent did the character (rather than merely the personnel) of different labour arrangements change? Did Partition contribute to more contractual labour relations? Did workers move from agricultural to nonagricultural employment, or the other way around? How did workers get access to new sources of income? Did wage dependency figure more prominently in post-Partition household living strategies? How did Partition shape borderland workers' identities? And

84. Hastings Donnan and Thomas M. Wilson, Borders: Frontiers of Identity, Nation and State (Oxford [etc.], 1999), chapter 5 .

85 . The best researched, and most high-tech, case is the US-Mexican border. See Donnan and Wilson, Borders, pp. 96-100, and many contributions to the Journal of Borderlands Studies. 
what role did these in turn play in the creation of subversive borderland economies which held state power at bay?

This essay commenced with a plea for a more thorough exploration of the landscape of knowledge and emotion known as "Partition". Studying how borderlanders worked their way through Partition opens up new perspectives with regard to the economic and social aspects of Partition, the living strategies of working people in periods of state fragmentation, and the role of such strategies in the formation of new states and nations. By connecting three dynamic but separate fields - Partition studies, labour studies and borderland studies - the study of labour in the Partition borderlands can enrich each of these. For borderlanders, working through Partition was a challenge in the past. For students of labour, it is one for the future. 